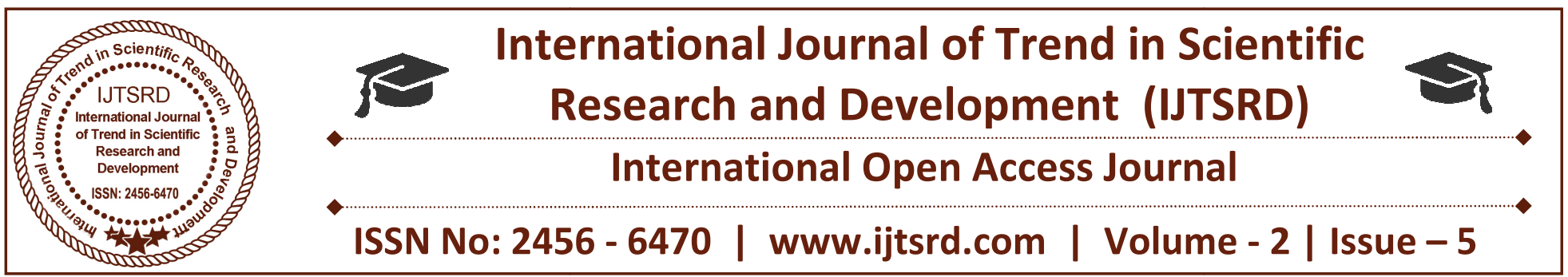

\title{
Black Money and its Impact on Indian Economy
}

\author{
Manish Dubey \\ BA, LLB, Indore Institute of Law \\ Indore, Madhya Pradesh, India
}

\begin{abstract}
In the present era, issue of BLACK MONEY has come into forefront of the society with active participation of our youth and parliament. Government took various steps about the problem of Black money. The main aim of this research paper is to know how it is generated, committees and report of black money. This paper represents the framework, policy options and strategies that Indian Govt. should adopt to tackle with this issue and also describes various measures taken by Government. It also studies the impact of Demonetisation on black money and also describes the size of Black money and also includes recent news of SIT. The corruption leads to its generation which has considerable impact on various sections of the society. At last but not least, conclusion of this paper is provided representing the ongoing issue of black money in our country and its future course of action. Hopefully, this would contribute to an informed approach on this issue as we move forward in this context.
\end{abstract}

KEYWORD: Demonetisation, Measures taken by government, Generation, Reports on Black money, SIT (Special investigating team).

\section{INTRODUCTION}

As we all know that our country INDIA is known as the golden bird in ancient time because in terms of coordination people of our country was more civilised. People worked hard honestly. They were not concerned about their earnings as compared to others. Our country INDIA was a prosperous nation and the reason about this prosperity was the high moral values and love for the mother land. The peoples of earlier time try to develop their nation by their efforts and contribution.
Current time Black money is the major issues in the development of our country. Black money is nothing but the unaccounted money which is circulated in our country. Black money is main cause of big loss in tax revenue of the government. It is a money which is generated by secret activities and the government had not know about this money and this money is not accounted for tax purpose or white money is that money which is shown with relevant account and tax that are paid.

In INDIA the main source which is used my ministers in elections to promote their own interest. Minister of our Indian political system major focus on personal growth instead of economic growth of their country, that's why in election they use massive amount of money to win, they just focus on double the amount which is spent by them in election by taking bribes even for smaller activities.

\section{Generation of Black Money}

Black money is generated through various activities some of them are given below.

\section{Corruption:}

It is generated by corruption which includes bribes given to and by public officers.

\section{High rated taxes:}

High rate taxes and overregulation result in concealment of income and a labyrinthine regulatory regime is an invitation to bribery.

\section{$>$ Illegal activities:}

It is earned through illegal means such as drug trafficking, weapons, trading, terrorism etc. 


\section{Trading:}

Hiding income through legal activities that is not reported to public authorities or we say to the government for the purpose of evade taxes. ${ }^{1}$

\section{Habitual not to paying the taxes:}

People become in the habit of not paying taxes.

\section{Various reports on Black money}

The government of INDIA has set up about 40 committees at different level to look into the issue of black money; some of the major committees are given below.

$>$ Corruption committee (1964).

$>$ Committee on Agriculture wealth and income (1972).

$>$ Indirect taxation enquiry committee (1978).

$>$ Tax reform committee (1992).

$>$ White paper on Black money (2012).

\section{Impact of black money on Indian economy}

There many consequences of Black Money some of them are given below.

\section{> Misdirection of precious natural resources:}

A part of black money instead of investing in productive activities is invested in conspicuous consumption and unproductive assets.

\section{Difficult to make correct economic analysis:}

The existence of black money is a big handicap in making a correct analysis and formulation of right economic policies. The government policies cannot be firm in their perception and design because of weak data base.

\section{Transfers fund from India to foreign countries:}

To earn black money, they transfer funds from India to foreign countries through secret channels. Such transfers are made possible by violation of foreign exchange regulations through the device of under invoicing of exports and over invoicing of imports. These are called Hawala transactions.

\footnotetext{
1 Manpreet Kaur and Akriti: Black Money in India: Current status and impact on economy: Abhinav National Monthly Refereed Journal of Research in Commerce and Management: Volume 4: Issue 4: April, 2015: at p. 35.

${ }^{2}$ Rajkumar S Adukia: Black money laws in India, 15 \& 16. http://www.caaa.in/Image/black\%20money\%20laws\%20hb\%20 080515.pdf
}

$>$ A threat to price stability:

Black money which is held in cash increases the liquidity power. Whenever the Government attempts to control excess demand to stabilize prices with the help of measures of credit control or rationing, such attempts are frustrated by the huge liquidity provided by black money. Since this liquidity results in heavy inventory build-up, it becomes a threat to price stability.

\section{$>$ Corrupting the political system:}

Black money has corrupted the political system. National policies are being bent in favour of the big businessmen under the pressure of black money. It is the parallel economy which does the back seat driving in policy decisions rules the nation in reality. The parallel economy poses a serious threat to stability and growth of the official economy. Black incomes are accentuating the inequalities in income and wealth and breeding a new class of 'black-rich' in our society.

\section{Administrative system to tackle transactions of} black money

Present administrative system of government to tackle black money transaction.

$>\mathrm{CBI}$ and Police authorities.

$>$ Enforcement directorate.

$>$ Financial intelligence unit.

$>$ State police agencies.

Central economic intelligence bureau.

- Central board of direct taxes (CBDT).

$>$ Integrated tax payer data management system. ${ }^{4}$

\section{Latest news about black money:}

SIT on Black money suggests RS 1 crore cap on cash holdings:

The team SIT is known as The special investigations team which is on black money has recommended the central government to cap the cash holding limit at Rs one crore instead of its earlier suggestion of Rs 20 lakh.

The SIT team has also recommended that the entire amount found in seizures crossing that limit should go to the government treasury; justice (retired) MB shah,

\footnotetext{
${ }^{3}$ Dr.S.R. Myneni, Indian Economics $164 \& 165$ (5 ${ }^{\text {th }}$ ed.2009)

${ }^{4}$ C.D. Bhosale and Nihal Mullaji: Measures taken over to bring back Black Money in India: Pune Research Discovery: An International Journal of Advanced Studies: Volume 1: Issue 3: at p. 3.
} 
who heads the SIT on black money, told PTI here today.

The latest recommendations come after the earlier suggested limits of Rs 15lakh and Rs 20lakh were found to be too low.

"We have recommended that the cap on cash holdings should be Rs one crore. We have also recommended that the entire amount seized above the cash holding limit of Rs one crore should go to the government," justice shah said.

The recommendation come after huge amount of tax were seized in recent search operation by tax authorities in the country.

The Income tax sleuths had on July 16 searched over 20 premises of a firm engaged in highway constructions and its associates companies in Tamil Nadu and seized Rs 160 Crore cash and $100 \mathrm{~kg}$ gold.

"The money which is seized is so high that now we are of the opinion that Rs20Lakh limit will not do," he said. Justice Shah had earlier suggested the cash holding limit to be at Rs 15lakh. However, later he had recommended to raise the limit to Rs 20lakh.

The SIT was formed by central government in 2014 on directions of Supreme Court. The panel has been continuously suggesting anti-black money measures to the government. ${ }^{5}$

\section{Impact of Demonetisation on Black money}

The Indian government launched a concerted drive against black money with Demonetisation being an important step in that direction. The main Objectives of Demonetisation was the flushing out of black money and also conversion of the non-formal economy into a formal economy to expand the tax base. The impact of Demonetisation on black money, widening of tax base and Direct Tax Collections is summed up hereunder:

\footnotetext{
5 The times of India, 19 July 2018, 18:13 IST https:/timesofindia.indiatimes.com/business/india-business/siton-black-money-suggests-rs-1-crore-cap-on-cashholdings/articleshow/65054805.cms
}

\section{A. Impact on black money: Quantum jump in Enforcement actions based on Demonetisation data:}

\section{Searches}

$>\mathbf{1 5 8 \%}$ increase in number of searches (from 447 to 1152 groups)

$\mathbf{1 0 6 \%}$ increase in seizures (from Rs. 712crore to Rs. 1469 crore)

$\mathbf{3 8 \%}$ increase in admission of undisclosed income (from Rs.11,226crore to Rs. 1,54,96crore)

\section{Surveys}

$>\mathbf{1 8 3 \%}$ increase in surveys (from 4422 to 12520

$44 \%$ increase in undisclosed income detected (from Rs. 9654crore to Rs. 13920crore)

\section{Operation Clean Money:}

The Income Tax Department launched 'Operation Clean Money' (OCM) on $31^{\text {st }}$ January, 2017 to analyse the data of the persons who deposited large sums of cash and whose returns of income were not in sync with such deposits.

\section{Phase 1:}

In the first phase of OCM, 18lakh suspect cases were identified through use of data analytics where cash transactions did not appear to be in line with the tax profile of depositors.

Online verification in these cases was enabled and done in a record time of 4 weeks.

The success of the first phase was also attributable to the massive taxpayers' awareness and media campaigns on Operation Clean Money launched by the Department.

The scale of the Operation may be gauged from the fact that response of 9.72lakh persons in respect of 13.33lakh accounts involving cash deposits of around Rs.2.89lakhcrore, as per pre-defined parameters on sources of the cash deposits was captured by the Income Tax Department within a short span of 3-4 weeks. Online queries were raised in more than 35000 cases and online verification was completed in more than 7800 cases.

\section{Phase 2:}

The Operation Clean money has since moved into the next phase that includes enforcement actions in high risk cases, taxpayer engagement through a dedicated 
website in medium risk cases and close monitoring in low risk cases.

The high, medium and low risk cases have been identified through use of advanced data analytics, including integration of data sources, relationship clustering and fund tracking.

The exercise has also unearthed large number of persons and clusters having suspect transactions. These include about 14,000 properties of more than Rs.1crore each where persons have not even filed Income Tax Returns. The investigations are in progress.

\section{B. Impact on Widening of Tax-base:}

The number of e-returns of Individual taxpayers filed till $5^{\text {th }}$ August, 2017 (due date of filing) increased to 2.79 crore from 2.22 crore returns filed during the corresponding period of last year, registering an increase of about 57lakh returns $(25.3 \%)$. This shows marked improvement in the level of voluntary compliance as a result of action taken by the Income Tax Department on the basis of data of cash deposits in the wake of demonetization.

The total number of all returns (electronic + paper) filed during the entire Financial Year 2016-17 was 5.43 crore which is $17.3 \%$ more than the returns filed during FY 2015-16.

For FY 2016-17, 1.26crore new tax-payers (return filers + non-filers making tax payments) were added to the tax base (till 30.06.2017).

\section{Impact on Direct Tax Collections:}

The effect of Demonetization is also clearly visible in the growth in Direct Tax Collections. Collection of Advance Tax under Personal Income Tax (i.e. other than Corporate Tax) as on 05.08.2017 showed a growth of about $41.79 \%$ over the corresponding period in F.Y. 2016-2017. Collection of SelfAssessment Tax under Personal Income Tax showed a growth of $34.25 \%$ over the corresponding period in F.Y. 2016-2017. ${ }^{6}$

\section{Size of Black Money}

While there is no official estimate of quantum of black money in India or abroad, a 2010 World Bank

\footnotetext{
${ }^{6}$ Press information bureau

http://pib.nic.in/newsite/PrintRelease.aspx?relid=170405
}

Report on shadow economies estimated it at 31 per cent of GDP of 162 countries with India's estimate pegged at 20.7 per cent of GDP. There have been other estimates which have placed size of India's parallel economy at higher levels including a recent FICCI report which has estimated it to as high as 75 per cent of GDP. As per a study conducted by Chandan Sharma, black economy as a percentage of GDP is quite substantial in India. However, on a positive note, study also indicates that fiscal reforms in important areas in 1990s helped in reducing the size of the black economy. Specifically, it was as large as $64 \%$ of the reported GDP in 1970s, in terms of current market value it was 280 billion Indian rupees. The size had gone down to $44 \%$ in 1997, but increase to 7000 billion rupees in value terms. More importantly, it has been constantly around $50 \%$ of GDP in the last two decades. In the last year of analysis, 2013, it was 52\% of GDP, which is around 60000 billion in Indian currency, while in terms of U.S. dollar, it was 957 billion. According to the 3rd report published in May, 2012, Swiss National Bank estimates total deposits by various countries.

Her also, India tops the chart, again reinstating the fact that a huge sum of black money is finding its way out of the country.

Table 1: Huge sum of black money is finding its way

\begin{tabular}{|l|l|}
\hline Country & Money deposit \\
\hline INDIA & \$1,456 Billion \\
\hline RUSSIA & \$ 470 Billion \\
\hline U.K. & \$ 390 Billion \\
\hline UKRAINE & \$100 Billion \\
\hline CHINA & \$ 96 Billion \\
\hline
\end{tabular}

Source: 2012 Report by Swiss National Bank

According to a report released by Global Financial Integrity (GFI) in December 2012, India is among the top 10 developing countries in the world with a black money outflow of $\$ 1.6$ billion (Rs. 8,720crore) in 2010. Total outflow of black money from India since independence until 2010 was $\$ 232$ billion, generally in the form of corruption, bribery and kickbacks. In the post-reform period of 1991-2008, deregulation and liberalization accelerated the outflow of illicit money from the Indian economy. About a third of India's black money transactions are believed to be in real estate, followed by manufacturing and shopping for gold and consumer goods. ${ }^{7}$

\footnotetext{
${ }^{7}$ Dr. Swaty Wadhwa and Sonal Pahwa : Curbing Black money : International journal of informative and futuristic research: Volume 4: Issue 11: July 2017: 8327
} 


\section{Measures taken by government}

\section{Measure to check tax evasion:}

Tax evasion is the source of generation of Black Money. Therefore plugging loopholes in tax laws by a large number of legal and administrative measures was undertaken. Most of these measures were based on the recommendations of various committees and commissions. Most of the recommendations pertained to improvement in tax laws. From time to time, the tax laws have been amended to arrest in evasion of taxes. At one time, the marginal rate of income tax was as high as $97.5 \%$ and they were gradually brought down to $40 \%$ in 1996 . They were reduced by Government in 1997-98 budget to $30 \%$ for individuals and $35 \%$ for corporations.

\section{Special Bearer Bond Scheme:}

This scheme was introduced in 1981 to channelize unaccounted money for productive purpose. They carry an interest of $2 \%$ per annum. Complete immunity has been granted to the original subscriber of the bonds from being questioned about the possession of bonds or about the sources of money from which the same have been acquired. The amount subscribed to this scheme is very meagre amount of Rs. 964crores.

The government measures described above have indeed achieved something. Bur this is too little considering the big size and complex nature of the problem. The sources of Black money remain as before, and the flow of such money continues.

\section{Voluntary Disclosure Income Schemes:}

This was adopted as far back as 1951 and then thrice in 1965, 1975 and again in 1997. The scheme envisaged a voluntary disclosure of concealed income by the persons. Under these schemes those declaring their income were not to be punished and they need not declare the source of income.

Some success was achieved. But the amount came out was very small compared to the black money. The new voluntary Disclosure Income Scheme which netted tax collections estimated to exceed Rs. 10,000 crores. $^{8}$

\section{Some suggestions to eliminate Black money}

$>$ Donation to political parties by companies should be banned.
$>$ Removal of control permits that are considered unnecessary.

$>$ The tax-net should be expanded to cover new taxpayers.

$>$ Competitive bids should be motivated.

$>$ The involvement of human beings more is the involvement of corruption, ultimately generating black money.

Agricultural income should be taxed for those who have both the agricultural as well as nonagricultural income.

$>$ The government should not give the absolute power for work to any person as its creates monopoly and instead should segregate the work among every person.

\section{Conclusion}

It is here by conclude that this paper contains different aspects of Black Money and its relationship with policy and Administrative measures of our country. Black money is the menace which definitely brings down the economy of the region.

The question which comes in everyone's mind that from where we generate money to face the price rise. Every rich man is living a luxurious and a powerful life. Citizens start adopting corrupt practises to earn money and one method is not to pay taxes. In country like India, to get efficient service one must depend on private sectors, like hospital, schools, These private sectors no doubt provide efficient and expected service but at a very high cost. If government would provide remarkable service, no common man would have to pay high price for every good service. There is need to change the mindset of the peoples and they have to understand that they are the sole reason for people to make Black money.

\section{References}

1. Manpreet Kaur and Akriti: Black Money in India: Current status and impact on economy: Abhinav National Monthly Refereed Journal of Research in Commerce and Management: Volume 4: Issue 4: April, 2015: at p. 35.

2. Rajkumar S Adukia: Black money laws in India, $15 \& 16$.

http://www.caaa.in/Image/black\%20money\%20la ws $\% 20 \mathrm{hb} \% 20080515$.pdf

3. Dr. S. R. Myneni, Indian Economics $164 \& 165\left(5^{\text {th }}\right.$ ed. 2009)

\footnotetext{
${ }^{8}$ Dr. S.R. Myneni, Indian Economics, 168 ( $5^{\text {th }}$ ed, 2009)
} 
4. C. D. Bhosale and Nihal Mullaji: Measures taken over to bring back Black Money in India: Pune Research Discovery: An International Journal of Advanced Studies: Volume 1: Issue 3: at p. 3.

5. The times of India, 19 July 2018, 18:13 IST https://timesofindia.indiatimes.com/business/india -business/sit-on-black-money-suggests-rs-1-crorecap-on-cash-holdings/articleshow/65054805.cms
6. Press information bureau http://pib.nic.in/newsite/PrintRelease.aspx?relid=1 70405

7. Dr. Swaty Wadhwa and Sonal Pahwa: Curbing Black money : International journal of informative and futuristic research: Volume 4: Issue 11: July 2017: 8327

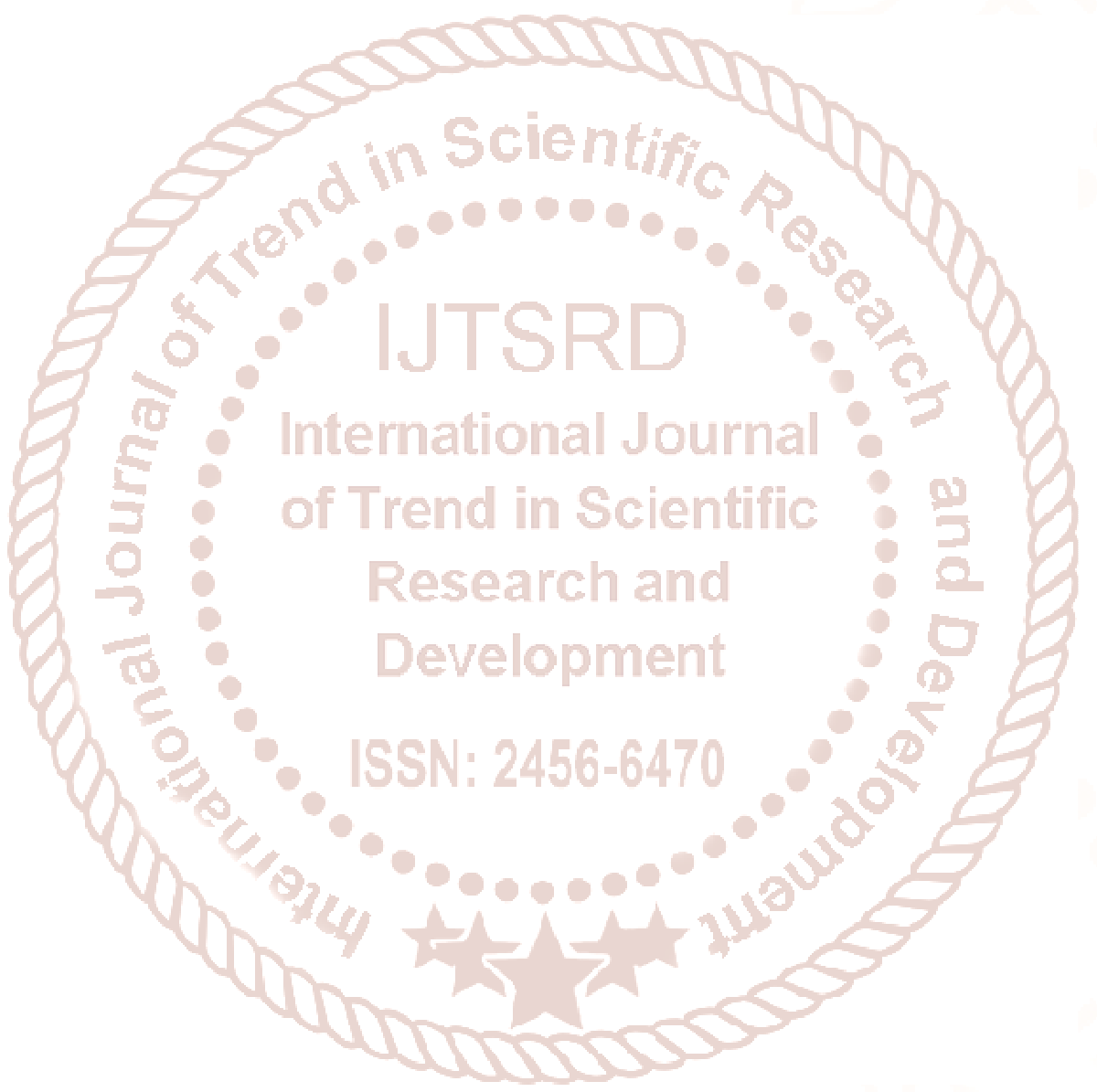

